\title{
Aproximações e diferenciações da Filosofia da Religião e da Teologia em Paul Tillich
}

\author{
Manoel Ribeiro de Moraes Junior ${ }^{1}$ \\ Fàbio Py ${ }^{2}$
}

\section{RESUMO}

Neste texto, pretendemos observar partes da trajetória intelectual do teólogo alemão-luterano Paul Tillich, principalmente, as que destacam a relação e diferenciação entre a filosofia da religião e da teologia. Para tanto, devemos nos deter no fragmento de "Tema e Método da Filosofia da Religião", que é uma parte integrante do livro "Filosofia da Religião" de Paul Tillich (1973), quando percebe a religião acima do pensamento moderno e iluminista, demonstrando que a filosofia deve abrir mão de designar à religião os seus interesses a fim de entendê-la na sua manifestação na cultura. Também, se visa esclarecer a relação entre a Filosofia da Religião e a Metafísica, evitando o mal-entendido que se reconhece no temo "metafísica", pois, sobre metafísica não se deve entender algo como uma ciência sobre os fundamentos últimos do mundo ôntico, mas como a atividade intelectual independente. Para designar mais ainda a idéia de metafísica, Tillich afirma que este saber não pode ser imaginado vinculado ao lado ou acima das ciências, mas de forma independente.

Palavras-chave. Paul Tillich, filosofia, filosofia da religião, teologia.

\footnotetext{
Graduado em Teologia STBSB, Mestrado em Filosofia UERJ, Doutorado em Ciências da Religião UMESP. Pós-Doutorado no CeSor/EHESS/CNRS e no PPGFIL UEPA. Professor na Universidade do Estado do Pará, Pós-graduação em Ciências da religião. E.mail: manoelmoraes@uepa.br.

2 Graduado em Teologia pela FABAT, Mestre em Ciências da Religião pela UMESP, Doutor em Teologia pela PUC-RIO. Pós-Doutor em Políticas Sociais pela UENF (FAPERJ). Professor convidado Programa de Pós-Graduação em Políticas Sociais na UENF. E.mail: pymurta@gmail.com.
} 


\section{SIMILITUDES Y DIFERENCIAS DE FILOSOFÍA DE LA RELIGI- ÓN Y LA TEOLOGÍA DE PAUL TILLICH}

\section{Resumen}

En este trabajo, se pretende observar partes de la historia intelectual del teólogo alemán luterano Paul Tillich, especialmente los que destacan la relación y las diferencias entre la filosofía de la religión y la teología. Por lo tanto, hay que detener el fragmento del "Tema y Filosofía de la religión Método", que es una parte integral del libro "Filosofía de la religión" Paul Tillich (1973), cuando se da cuenta de la religión por encima de la Ilustración moderna pensado, lo que demuestra que la filosofía debe dar para designar la religión de sus intereses con el fin de comprenderlo en su manifestación en la cultura. Asimismo, se pretende aclarar la relación entre la filosofía de la religión y la metafísica, evitando el mal entendido que reconoce el término "metafísica" a causa de la metafísica no se refiere a algo como una ciencia sobre los fundamentos últimos del mundo óntico, sino como una actividad intelectual independiente. Para describir con más detalle la idea de la metafísica, Tillich dice que este conocimiento no puede ser imaginado vinculado a un lado o encima de las ciencias, pero de manera independiente.

Palabras-claves. Paul Tillich, filosofía, filosofía de la religión, la teología

\section{Introdução}

$\mathrm{O}$ artigo investiga questões metodológicas do pensamento filosófico sobre a religião esboçadas no texto intitulado "Tema e Método da Filosofia da Religião" - texto que é parte integrante do livro "Filosofia da Religião" de Paul Tillich (1973). No livro, Tillich visualiza a religião para além dos interesses exclusivistas do pensamento moderno e iluminista (HIGUET, 2011, p. 27-29; DANZ, 2001, p. 173-188). Diferentemente de Kant, que se propõe a analisar e demonstrar as possibilidades da "razão pura" em esclarecer e julgar o bom uso da moral e religião, Tillich entende que a filosofia deve primeiramente esquivar-se das tentações imperativas de designar à religião os seus interesses e os seus objetivos (PIEPER, 2015). Em seguida, procurar adotar uma postura epistemológica mais fraca para poder entendê-la na sua dialética 
formativa e sua manifestação na cultura (CALVANI, 1998, p. 45-51). Ainda mais, interpretar, compreender e explicar o teor e as formas da religião a partir dos seus imperativos absolutista e transcendente - reconhecendo a filosofia no contexto das "ciências do Espírito"3 (Geisteswissenschaften) de Wilhelm Dilthey.

\section{Sobre o problema do objeto (a religião)}

Ao pensar teórico e arquitetonicamente o objeto da filosofia da religião, Paul Tillich tem consciência de que a esfera cultural que expressa o sagrado resiste em reduzir-se às formas, às possibilidades e aos limites que a razão procura the estabelecer (PIEPER, 2015; MORAES JUNIOR, 2010). Isso porque toda aspiração de uma inquisição teórica se regra metodologicamente ao lançar-se às perguntas sobre as coisas e os acontecimentos do mundo dos homens e da natureza. A princípio, esta distinção inconciliável de saberes mostra-se resistente por consequência das atribuições investigativas que a filosofia dispensa na sua rotina reflexiva. Não é por menos, considerada como saber antecâmara das ciências e de toda razão lógico-teórica, a filosofia procura estabelecer ou reconstruir a normatividade da especulação objetiva, ética e estética a partir de referenciais internos (logocêntricos). ${ }^{4}$ Mesmo que mais tarde este saber torne-se consciente das dimensões falibilistas do pensar, esta normatividade almeja formalizações que inevitavelmente recebem o status de universais, pois a formalização racional é necessária para que a pluralidade dos

${ }^{3}{ }^{1}$ Para Wilhelm Dilthey o homem só era capaz de conhecer o mundo do espírito, isto é, da realidade histórico-social, e a natureza não pode ser conhecida pelos seus fundamentos últimos, mas apenas pelo espírito do homem. Ele distingue ciências da natureza (levadas pelo mecanismo de explicação) e as ciências do espírito são as que são levadas pela ideia de compreensão, típica hoje das ciências humanas, vide, DILTHEY, 1949, p.78-79.

$4 \quad{ }^{2}$ Sobre o importante papel da filosofia tanta na universidade, quanto como saber formativo que compõe uma variada sensibilidade desde a expressão do pensamento, dos sentimentos, dos desejos e ações, mas, sobretudo como modo de vida, de questionamentos até a construção das hipóteses, vide CHAUI, 2003, p.8-9. 
fenômenos seja coordenada por um sistema único de identidades (uma ontologia - CHAUI, 2003, p. 8-15).

Paul Tillich é consciente de que o religioso não persegue e nem se vê sobrevivente sob os cuidados ou requisições universalistas da razão ocidental. Para ele, as imagens da(s) religião(ões) buscam aferir seus participantes ao singular-absoluto arrolado naquilo manifesto de modo incondicionado (GROSS, 2013, p. 10-13; TILLICH, 1985, p. 24-26). Por isso, uma "revelação" ou um ato de "redenção" opõe-se a um conceito especulativo e específico de religião: não por menos, os atos religiosos "originários" rompem com a ordem estabelecida, o cotidiano, o fático no qual se constroem a rotina da ação e do pensamento humano figurados num contexto cultural (TILLICH, 1985, p.24-26).

'Revelación' se refiere a una acción divina, 'religión' a una acción humana. 'Revelación' es un acontecimiento (happening) absoluto, singular, exclusivo y auto-suficiente; 'religión' tiene que ver con hechos meramente relativos, siempre recurrentes y nunca exclusivos. 'Revelación' significa la entrada de una nueva realidad en la vida y el espíritu; 'religión' nos remite a una realidad dada de la vida y a una función necesaria del espíritu. 'Religión' tiene que ver con la cultura. Por esta razón, la religión siente que se ha violado su esencia más profunda cuando se la denomina religión (TILLICH, 1973, p. 09-10).

Ora, de um lado, a Filosofia da Religião sabe-se distinta da teologia enquanto ciência da revelação, do outro não pode admitir uma imposição de silêncio à razão especulativa - pois tal impotência reflexiva se estenderia também às outras áreas do saber além da própria Filosofia da Religião. Como a razão inquiridora pode se silenciar diante da religião e de suas expressões socio-

5 É importante notarmos que, para salvaguardar a religião das formas tradicionais de especulação erguidas pela filosofia e pelas ciências sociais, Tillich distingue religiões em mais ou menos pura, original e forte. Talvez, seguindo esta linha de raciocínio, o filósofo e teólogo alemão ainda pense o religioso sob etapas reconstrutivas que postulam uma origem extra-ordinária, como aquela proposta por Rudolf Otto na sua obra Das Heilige (1917), e depois desenvolvida em pesquisas sociais mais amplas como as de Mircea Eliade. Por isso, afirma James Luther Adams que "what is needed is a method of phenomenological intuition and a dynamically developed critical metod. This means that Tillich believes the demand is for the metalogical method" (ADAMS, 1965, p.191). 
culturais? Para isso, a Filosofia da Religião deve primeiramente reconhecer-se num espaço de antíteses. Isso porque o conhecimento filosófico e a religiosidade hipoteticamente cognoscível estão separados por uma fronteira. No local onde ocorre o encontro entre ciência e fé há interesses distintivos, contudo, o encontro nem sempre é de antagonismos: fé e especulação. Neste lugar também coabitam duas ciências: a filosofia e a teologia (PIEPER, 2015).

Olhando retrospectivamente a história do pensamento ocidental, Tillich percebeu que estas duas grandiosas criações da cultura intelectual, a teologia e a filosofia, mantiveram laços de complementaridade - já presentes no período clássico, na alta idade média, no romantismo alemão e outros momentos históricos - e de distinção auto-afirmativa - no cartesianismo, no empirismo inglês, criticismo kantiano, no puritanismo anglo-germânico e nos movimentos fundamentalistas do protestantismo norte-americano (TILLICH, 1992, p. 32-67; TILLICH, 1986, p. 19-25). Para Paul Tillich (1973, p. 1-18) a luta por uma sobrevivência exclusiva entre estas duas ciências abalou tanto as pretensões necessárias de um saber crítico e investigativo como aquelas de um saber necessário do incondicionado que se expressa na religião: por isso, afirma "Y sin embargo, no se puede permitir que subsista la oposión, porque conduce al quebrantamiento de la unidad de la conciencia y a la disolución, sea de la religión, sea de la cultura" (TILLICH, 1973, p. 11).

Mesmo que distintas e muitas vezes em tensões, a Filosofia da Religião deve buscar uma solução sintética entre a filosofia, a teologia e as expressões religiosas (GROSS, 2013, p. 10-13; TILLICH, 1985, p. 24-26). Do ponto de vista metodológico, cabe à Filosofia da Religião investigar as possibilidades de existência de um ponto convergente entre filosofia e teologia para que daí, se abram possibilidades de um saber teórico aliado aos ideais investigativos das ciências humanas (RIBEIRO Jr, 2010, p.7879). Isto implica na emergência de um saber mais sensível às alteridades simbólicas ancoradas nas formas absolutas e singulares das expressões das religiões. 


\section{A Filosofia da Religião como Saber}

Paul Tillich (1973, p. 11-34) discute sobre o teor epistemológico e o modo como a Filosofia da Religião pode ocupar o quadro sistemático das ciências. Para tanto, Tillich pressupõe a divisão proposta por Wilhelm Dilthey (1949, p.78-79) entre as "ciências do espírito" (Geisteswissenchaften) e as "ciências da natureza" (Naturwissenchaften). Mesmo que a Filosofia da Religião seja um saber a fim ao primeiro tipo de ciência, é importante esclarecer à luz de uma teoria sistemática do conhecimento (Wissenschaftsystematik) as condições abertas a ela para sua adequação ao quadro das ciências (DILTHEY, 1949, p.81-93).

Os temas de pesquisa que giram em torno da religião abrem um campo de pesquisa em que a "situação de discussão" sobre a objetividade e a cientificidade do investigado acontece em espaços fronteirísticos de saberes e ações humanas (CALVANI, 1998, p. 132-145). "Espaço de fronteira" pode ser considerado uma metáfora epistemológica daquilo que se alude como as possibilidades de encontros entre alteridades de ações e conhecimentos irredutíveis uns aos outros (TILLICH, 1976, p. 67-69). Esta situação expõe toda a fragilidade de um jogo epistemológico ao tentar compreender (Verstehen) e esclarecer (erklären) exaustivamente o investigado, sobretudo num momento pós-metafísico de pensamento. Tal discussão exige da própria "teoria do conhecimento" considerações reformuladoras de si mesma, pois o objeto, a religião, exige uma reconsideração mais apropriada das suas possibilidades singulares de conhecimento teórico (TILLICH, 1973, p. 11-34).

Porém, como se indicou no primeiro tópico, pensar o religioso requer também repensar a própria dimensão de suas possibilidades de estudos científicos - pois o religioso é manifesto num espaço de fronteira. O foco das reflexões epistemológicas que buscam imprimir à religião um status de objeto de estudo teóricos (Wesensschau) é um passo necessário Isso porque sem ela, não é possível se configurar o status de ciência dos saberes que elegem 
a religião como tema de suas investigações - neste caso, temos o desafio claro às Ciências da Religião. Por isso afirma Adams:

The determination of the place of philosophy of religion - a branch of philosophy - in the system is important not only for philosophy of religion; it is equally important for the system. Each is affect by the other. The system of the sciences is conditioned by the conception of science, and since science in general is brought into question by the basic problem of philosophy of religion, it is conditioned decisively by philosophy os religion. A systematization of the sciences is in its totality dependent upon the solution of the problem of philosophy of religion (ADAMS, 1965, p. 187).

Uma nova compreensão do espaço e da atuação da filosofia da religião - um ramo da filosofia - no sistema dos saberes teóricos não é importante somente para a sua auto-referencialidade, mas também, igualmente importante para o sistema dos conhecimentos científicos. Isto porque, pensa Paul Tillich, a autocompreensão dos saberes torna todos eles interdependentes entre si porque suas autocompreensões devem compor um mesmo tecido: o sistema das ciências. Um depende do outro. O sistema das ciências está condicionado à concepção de ciência (TILLICH, 1973, p. 11-34). Assim, a ciência em geral é colocada em questão pelo problema básico da filosofia da religião, algo condicionado decisivamente por ela mesma. A sistematização das ciências esta, em sua totalidade, dependente da plena solução do problema da filosofia da religião (TILLICH, 1976, p. 67-69).

Ao invés de seguir passos autoreferenciais na própria Filosofia da Religião, Tillich esclarecerá a questão explorando teias funcionais do sistema de conhecimento científico em que a religião é tema de investigação.

\section{A Filosofia da Religião, Teologia e Ciências Empíricas da Religião no Contexto das Ciências do Espírito}

Tillich (1973) não tem dificuldades em enquadrar a Filosofia da Religião no sistema das Ciências do Espírito. Ela é uma área da filosofia que procura criativamente arrematar conceitualmente 
a tudo que é expresso como religioso. Mas para isso, ela deve observar os materiais de pesquisa desenvolvidos pela história das religiões, psicologia da religião, antropologia da religião, sociologia da religião, literatura comparada etc., sem confundir em nenhum momento quaisquer ciências com outras. Isso porque a Filosofia da Religião não procura estabelecer uma significação de identidade local para o religioso (Seiendes), mas somente reconstruir aquilo que é válido como abrangentemente religioso (Gültiges) (BRISSON, 2003, p. 26-28). Desta maneira, os fatos empíricos reconstruídos pelas ciências e o próprio processo de reconstrução dos fatos verificáveis, não são tomados objetivamente pela Filosofia da Religião, mas somente como recurso analítico (material) para a realização de sua tarefa conceitual (BRISSON, 2003, p. 26-28).

$\mathrm{Na}$ exposição sobre a natureza de qualquer ciência, abre-se pelo menos três elementos que lhe estão embutidos: 1) uma filosofia, 2) uma história cultural e uma 3) sistemática (Systematik). $\mathrm{Na}$ filosofia se organizam os significados e as categorias do saber em estudo. Na história cultural, se sistematiza o material oriundo das ciências empíricas. E, por último, na sistemática procura-se organizar todo o saber pretendido segundo os cânones tipológicos da ciência em ação.

Procede de una función universal del espíritu y de las formas, mediante la que se constituyen, em ella, los objetos. Después, examina de manera crítica la actualización de esta función esencial enl as diversas direcciones del desarrollo histórico. Por último, ofrece su propia solución teórica, a partir de los problemas que son traídos a un primer plano por la conceptualización de la esencia de la cosa y por historia cultural (TILLICH, 1973, p. 15).

Seguindo este tripé, Tillich aplica estes elementos das ciências do espírito à filosofia da religião, à história cultural da religião e à teoria sistemática da religião (a teologia), com a finalidade de esclarecer a dinâmica das ciências culturais (do espírito) da religião. A Filosofia da Religião herda a tarefa de ocupar-se com a investigação teórica da função e das categorias do religioso, 
enquanto a teologia designa-se à função de sistematização e normatização dos significativos manifestos da religião (JOSAPHAT, 2013, p. 83-87). Por último, a História Cultural fica incumbida da tarefa de estabelecer pontes entre a filosofia da religião e a teologia (TILLICH, 1973, p. 14-16), captando:

De manera crítica las realizaciones individuales del concepto de religión em lahistoria, y de este modo conduce hacia una solución sistemática especial, que le es propria y característica (que puede ser la solución de un grupo, de una "escuela" o de una Iglesia) (TILLICH, 1973, p. 16).

Ao tratar a Filosofia da Religião no interior correlativo das ciências do espírito da religião, Tillich indica a este ramo da filosofia um exercício dinâmico e falibilista que busca insistentemente associar os conteúdos do mundo-vivido na tentativa de compreender a validade religiosa (TILLICH, 1973, p. 14-16). Desta maneira, impõe-se assim a este saber uma renovação epistemológica afim à nova hermenêutica e à fenomenologia proto-husserliana. Assim sendo, segundo o próprio Tillich, "la filosofía de la religión sería abstracta e indistinta si no se tomaran en cuenta la historia cultural y la teología” (TILLICH, 1973, p. 16-17).

Mesmo apontando o tema da religião e de suas respectivas ciências para além dos restritos tratamentos metódicos dispensados nos círculos positivistas das ciências sociais tradicionais, estas apreciações ainda são preliminares para Tillich. Para o teólogo alemão (1973, p. 19), tratou-se até aqui a religião e a teologia como função e saber diluído nas diversas funções sociais e nas diversas disciplinas das ciências do espírito. Cabe então, de uma forma mais apurada, investigar uma ideia de religião que reverencie a sua amplitude nas amplas dimensões sociais. Desde Hegel (2008, p.67-96), esta ampla dimensão social é denominada "Espírito Social": a ordenação sintética material e não material, histórica e multiplamente experiencial. Assim, afirma Etienne Higuet:

O espírito é definido como a síntese do pensamento e do ser. É o princípio de todas as funções espirituais, tanto práticas quanto teóricas, assim como a natureza é o princípio das funções naturais em todos os níveis, 
físicos, biológicos, psicológicos e sociológicos. O espírito é, assim, princípio de toda a atividade cultural e as ciências do espírito (Geisteswissenschaften) são identicamente as ciências da cultura. (HIGUET, 2011, p. 31)

No contexto das Ciências do Espírito e entendendo que as expressões religiosas escapam às expressões lógicas disponíveis ao investigador, Paul Tillich sugere às ciências imbuídas com os estudos da religião a adequação da metodologia metalógica às suas práticas teóricas. Isso porque, para Tillich, a procura pela interpretação e compreensão das expressões da religião busca atender a pretensões de validade que podem ficar restritas a um jogo específico de linguagem ou de uma lógica de recepção interpretante. Por isso, Tillich apresenta a pertinência do método metalógico. Pois, para o próprio Tillich, "responde-se à questão da verdade da religião ao apreender de modo metalógico a essência da religião como orientação para o sentido incondicionado" (TILLICH, 1959, p.327).

Os referenciais teóricos mais contundentes da Teoria Crítica tardia de Max Horkheimer, a saber: Marx, Weber, Schopenhauer e Freud, são aqueles mesmo que mais expressaram um grande impacto crítico às tradições intelectuais, culturais e sociais do ocidente, logo, à religião. Destes quatro intelectuais, Max Weber, com sua sociologia interpretativa, e Sigmund Freud, através da psicanálise, serão os autores que mais ecoaram na última fase intelectual de Horkheimer.

Araújo (1994, p. 15-41) ${ }^{6}$ afirma que a religião em Weber é uma expressão de "visão de mundo" que pode ser investigada a partir de três tipos ideais: primeiro, pelo potencial mágico que ela exerce na compreensão social do real; segundo, na coordenação compreensiva que ela desprende enquanto constituinte racional das formas internas de organização social (estratificação social) e, terceiro, enquanto fundamento da "auto-compreensão social" a partir da qual se fundamentam as concepções de bem, as mesmas que guiam os postulados da plena satisfação. Um conceito delimitativo da religião em si não é do interesse direto de Max

Vide também as seguintes obras: PIERUCCI, 2003, p.56-58; WEBER, 1999; 1996. 
Weber, posto que o que lhe interessa são as formas de racionalidade com as quais ela atua conglomeradamente para a definição e para a transformação das visões de mundo e também para com as formas de organização social.

A outra forte referencia teórica de Horkheimer é a psicanálise de Sigmund Freud. O pai da psicanálise moderna investigou a religião no contexto de suas pesquisas sobre os comportamentos patológicos, tais como a neurose, a psicose e outras sintomatologias, que se manifestassem fenômenos bio-comportamentais nocivos ciclicamente ao corpo e às relações intrapessoais (PALMER, 2001). Para o desenvolvimento de suas pesquisas, Freud desenvolveu uma teoria da cultura em diálogo com as teorias comportamentais da psicologia clássica e, também, em diálogo para com as teorias fisiológicas. Na constituição de sua ciência interdisciplinar sobre o ser humano, Freud procurou reconstruir as estruturas da personalidade, como também a sua constituição através do processo dinâmico de socialização lingüística e a funcionalidade fisiológica de cada indivíduo. Com isso, o conceito de ser humano proposto pela psicanálise freudiana desconstruiu as imagens clássicas da significação e da identidade humana.

Para Freud, aquilo que se identificava como "eu" (ego) não poderia ser considerando a dimensão fundamental dos indivíduos que agem no mundo. Para o psicanalista austríaco, o ser humano socializado (o ego) é uma expressão das necessidades pulsionais (id) regulados pelas estruturas normativas externas (super-ego ou a trans-individualidade) que regulam os desejos individuais e o agir de cada indivíduo (FREUD, 1997, p. 48-56) lutando por propiciar importante vivência coletiva. Contudo, este processo de socialização não acontece sem provocar infortúnios, conflitos e mal-estares (FREUD, 1997), pois ele incentiva a manifestação dos desejos (das expressões agressivas e eróticas) singulares para, logo em seguida, impor-lhes limites, a tolerância pública. Assim, a religião, como sistema simbólico memorial (ASSMANN, 2008, p. 51-67), expressa duas dimensões antropológicas: de um lado, ela se mostra como sistema de valores simbólicos que expressa aquilo que cada ser humano tem de mais original em sua vida, 
ou seja, a carência paterno-uterina de algo seguro e também de algo que lhe sacie os "impulsos de desejos" - aqueles mesmo que buscam, no final das contas, realizar carências de proteção e felicidade; do outro, a religião exerce o papel normativo de regular o comportamento social, impedindo que as pessoas assumam autonomamente as suas decisões mais vitais. ${ }^{7}$

Somente à luz da perspectiva freudiana, pode-se compreender que a religião favorece um retardo no processo de amadurecimento social e da autonomização dos indivíduos, por escravizá-los aos tratos mais infantis dos desejos corpóreos e menos às exigências intelectuais de compreensão e decisão no mundo (PALMER, 2001, p. 66-70). Contudo, Herbert Marcuse é crítico a esta tese. Mesmo seguindo os passos de Freud, Siebert (SIEBERT, 1982, p. 27-36) lembra que Marcuse (MARCUSE, 1968, p. 132-145) encontra na religião uma ambivalência fundamental: a tensão que ela contém entre suas próprias imagens, por um lado, da dominação e, por outro, de emancipação. De um lado ela cumpre a estabilidade do status quo, mas, do outro, ela também pode conservar severas aspirações à liberdade, à melhoria da vida com menos expressões de sofrimento. Desta crítica, pode-se concluir que existe uma dimensão originária da religião que não pode ser reduzida às possíveis formas de uma determinada racionalidade ou a um sistema de normas sócio-culturais. Destas formas negativas da religião, a filosofia, já no romantismo, investigou suas dimensões mais originárias.

O estreitamento entre teologia, cultura, filosofia e religião foi preconizado por pensadores como Kierkegaard, Schleiermacher, Jaspers, Scheler, Dilthey e outros influenciados pelo espírito romântico europeu. ${ }^{8} \mathrm{O}$ mundo heterônomo à razão autônoma, científica e ensimesmada, desde o iluminismo nos tempos de Imma-

7 Sobre isso, afirma Assmann que "a teoria freudiana da religião tem o mérito indiscutível de ter indicado as dimensões psíquico-históricas da história da religião, o papel central do esquecimento, da lembrança e da repressão, tanto como o trauma e a culpa" (ASSMANN, 2008, p. 86).

8 Encabeçados por F. Schleiermacher, estes pensadores envolveram-se com a reflexão sobre a religião de modo a libertá-la das exigências de uma razão científica e de uma moral burguesa. Para mais, cf. BINGEMER, 2003, p.87-117. 
nuel Kant, impulsionou reações como a do romantismo intelectual (Beethoven, Chopin, Novalis, Holderlin etc.) ${ }^{97}$. A razão formal tinha se esvaziado da vida e da natureza, contudo, a religião e a arte, na contramão dos imperativos teóricos, se prontificaram em reconciliar mulheres e homens às dimensões perdidas da vida, do desejo, do sentimento, etc.. O pensamento romântico preocupou-se em repensar a dimensão autenticamente humana e, assim, se constituiu insatisfeito. Quando evitaram trilhar exclusivamente as veredas das ciências da natureza e da lógica, os intelectuais românticos descobriram as experiências do sagrado e da arte como expressões que também os conduziam ao aberto e fenomênico Mundo do Espírito (BRÜSEKE, 2004, p.205-216).

A obra do teólogo alemão Rudolf Otto, O Sagrado (Das Heilige, 1917 - OTTO, 1985, p.78-79), antepõe-se às compreensões de religião conjecturadas pelas clássicas Ciências Sociais e Humanas da religião, revelando que esta esfera de experiência, ação e significação pode ser compreendida teoricamente em duas instancia: 1) uma epistêmica, no qual "religião" ganha o status de realidade primária de investigação, enquanto conceito-elementar (tornado possível através de redução eidética, elementar) à sua experimentação possível: o "sentimento de numinoso" (sensus numinis); 2) a outra ocorrencial, pois enquanto objeto primário de pesquisa, a experiência religiosa se expressa de forma aberta e, simultaneamente, vinculada a dois sentimentos: o tremendo mistério (mysterium tremendum), o mistério fascinante (fascinans mysterium). Assim, o teólogo Rudolf Otto propõe uma compreensão da anterioridade da religião ante o seu uso tradicional, ético, cultural, social etc., ou seja, anterior a uma compreensão da religião como expressões sócio-culturais da religiosidade. Seguindo este caminho, pode-se dizer que, após estas considerações de Otto, a religião ganhou o status de realidade antropológica,

9 Sobre esta virada na forma estética de pensar o mundo, a sociedade e o ser humano, afirma Bosi: "Infinito anelo. Nostalgia do que se crê para sempre perdido. Desejo do que se sabe irrealizável: a liberdade absoluta na sociedade advinda com a revolução de 89 . $\mathrm{Na}$ ânsia de reconquistar "as estações mortas" e de reger os tempos futuros, o romantismo dinamizou grandes mitos” (BOSI, 2006, p. 95). 
por originar experiências e signos os quais a revelam uma esfera própria de expressão cultural.

Sobre esta anterioridade da experiência originário-religiosa, Martin Heidegger afirma que o pasmo e a admiração mística antecedem à plástica e à semântica religiosa. Ou seja, a epoché mística, que expressa uma claridade ou uma iluminação, não é só anterior, mais ainda, é instigadora da formação da ordem significativa do mundo, dos valores (HEIDEGGER, 1997, p. 167168). Partindo desta mesma tese, anos depois, Heidegger fala que o pensamento sobre as dimensões essenciais deve ir além das simples ontologizações das coisas, e partir para a compreensão da experiência clarificação/silêncio como abertura do cenário de onde o poeta místico nomeia o sagrado e, desta forma, "cuide da linguagem" para que ela, abrigando a "verdade do ser", chegue ao dasein em sua plenitude. Como afirma heidergger, "o pensador diz o ser, o poeta nomeia o sagrado" (HEIDEGGER, 1983, p. 51). Com Heidegger chegamos à "reserva compreensiva" comum entre a Teologia e a filosofia da religião.

Após as publicações de alguns ensaios sob o título "A substancia religiosa da cultura" do teólogo protestante Paul Tillich (TILLICH, 1967, p. 13-31), favoreceu-se o desenvolvimento de pesquisas sobre as dimensões mais elementares da religião e da cultura, inspiradas nas teses dos pensadores românticos e pós-românticos que criticavam o monopólio intelectual da razão tradicional e, do mesmo modo, favoreciam uma compreensão mais alargada da religião. ${ }^{10} \mathrm{O}$ teólogo alemão Paul Tillich, favoreceu um intenso diálogo metodológico entre a Teologia e a Filosofia. Este diálogo favoreceu uma superação das questões positivas da razão, a mesma que foi responsável pela batalha auto-afirmativa entre estas duas áreas do conhecimento teórico. A Teologia e a

10 Segundo Ribeiro, "Paul Tillich, portanto, sofreu forte influência romântica. Marcado pela "Gothic perfection" estabeleceu uma relação com a natureza na qual prevalecia a atitude estético-meditativa ao contrário da relação científica-analítica ou técnica-controladora. Essa é a razão do interesse dele por Schelling, o que influenciou, por exemplo, a "doutrina da participação da natureza no processo de queda e de salvação” (RIBEIRO, 2003). 
filosofia da religião de Tillich fizeram com que estas duas áreas cooperassem entre si na seguinte questão: quais as possibilidades e os limites de um encontro entre a filosofia e a teologia, com a finalidade de se conhecer a dimensão significativamente profunda da religião, e também sua importância para as expressões intelectuais (artísticas, culturais, teóricas etc.).

A teoria interdisciplinar sobre a religião em Tillich revelou que tanto a Teologia quando a Filosofia fossem saberes portadores de uma potencial cooperatividade teórica daquilo que se pode chamar de "reserva compreensiva"11 sobre a religião. Esta "reservaa compreensiva" é uma luta teórica por reconstruir a constituição experiencial de vivencia e significação humana, enquanto a mais elementar da existência e do agir humano. Assim, nesta tentativa de levar às últimas conseqüências a máxima romântico-moderno de se compreender a constituição (Bildung) do objeto da pesquisa, tanto a Teologia quanto os Estudos Literários se descobriram num trânsito comum: a constituição mais originária do ser-humano (enquanto ente bio-significativo) manifesta-se conjuntamente em signos ou em exclamações apofáticas de fé - considerando tênues e quase indivisíveis estas duas dimensões.

Certo é que "Teologia" e a filosofia da religião encontram-se complementares ao alcançarem cada uma a correlação elementar

11 Sobre esta cooperação metodológica na investigação da religião, afirma Higuet que "junto com Jean Ladrière, vemos nas ciências humanas em geral e na teologia em particular ciências de tipo hermenêutico. Isto é, a chave de compreensão dos objetos com os quais elas se ocupam encontra-se num significado ou num sistema de significados. Parte-se do pressuposto que a ação humana e os objetos produzidos por ela contém intenções significantes e que o esforço de compreensão que lhes diz respeito só pode consistir em reconstituir essas intenções. As hipóteses desempenham a função de sugerir uma organização plausível de sentido, verificável por intermédio de certos raciocínios, em confronto com os dados disponíveis. Trata-se de alcançar totalidades significantes cada vez mais abrangentes, onde cada elemento possa encontrar a sua justificação, até chegar a uma ? ?saturação de sentido? sempre provisória. Resulta daí que as ciências humanas ou sociais são apenas muito parcialmente empíricas e são antes de tudo hermenêuticas. A coisa se torna mais flagrante ainda quando acrescentamos as ciências da linguagem (linguística, semiótica, filologia...) e a história, sem falar na filosofia" (HIGUET, 2010). 
entre a dimensão semântica e a experiência vital (Erfahrung), a vida e a linguagem, a fé e a arte. O diálogo entre estas duas áreas do saber reconhece a importância da "reserva compreensiva" que cada uma destas ciências desenvolve sobre a originalidade humana, "lugar/momento" de onde nasce a cultura. ${ }^{121}$ É nestas dimensões autenticamente e originariamente humanas que se descobre o instante antropológico do qual brota intenso poder de experiência (Erfahrung), fé (Glauben) e criação (Erschaffung) todas elas anteriores às formas de religiosidade ou do estado atual da arte (que podem ser compreendidas como aquelas apolíneas, nos dizeres de Friedrich Nietzsche - NIETZSCHE, 1993).

Paul Tillich encontra uma grande afinidade entre a religião, a cultura e a arte. ${ }^{13}$ Sobre a religião, para o teólogo alemão a sua dimensão não pode ficar restrita ao "dom da revelação divina" (teologia dogmática) e nem como algo conseqüentemente restrito à dinâmica psíquico-social, reduzida "apenas a uma criação transitória do espírito humano, mas nunca sua qualidade essencial" (Ciências sociais - TILLICH, 1967, p.13-31). Sob a influência da ontologia de Nicolau Hartmann, da romântica e substancial ideia correlacional entre religião e cultura em Friedrich Schelling (STO-

12 Para Higuet, "Tillich dá mais importância à religião como atitude presente em todos os setores culturais - especialmente no campo secular ou profano -, como dimensão de profundidade da cultura ou abertura à profundidade inesgotável da verdadeira criação cultural. Esse novo conceito deve se fundamentar na experiência do Incondicional. A religião é a substância da cultura que, por sua vez, é a forma da religião. A tarefa da teologia como "teologia da cultura" será de estudar o teor religioso de toda cultura e de toda forma cultural. Em particular, pelo deciframento do estilo de uma cultura, o teólogo pretende alcançar dois níveis de sentido: 1 . Um nível preliminar, que é o sentido direto e conscientemente visado por essa cultura, e não é habitualmente um sentido estritamente religioso. Trata-se de alcançar a unidade de sentido que se expressa de modo simbólico imanente através das formas autônomas da cultura. A teologia compartilha essa tarefa com as ciências da religião; 2. O "sentido do sentido", o sentido último mais profundo no qual se fundamenta o sentido preliminar, imanente e formal de toda cultura e de todas as suas formas particulares. A teologia expressa a sua especificidade na procura do sentido último ou incondicionado" (HIGUET, 2006).

13 Sobre a relação entre religião, a cultura e a arte foi desenvolvida na tese de doutoramento de Carlos Eduardo Calvani (1998), no seu texto que relaciona Teologia e a MPB, partindo sempre da noção de cultura e de religião do teólogo Alemão. 
NE, 1978, p. 11-44; GROSS, 2004, p.79-99; PY, 2016, p.131-135), e da dimensão antropologica trágica (STONE, 1978, p. 11-44), mas levada da vontade de querer viver de Schopenhauer, Tillich entendeu que a religião e a cultura se irmanam na profundeza (Tiefe) espiritual (Geist) da vida (Leben) (TILLICH, 2009, p. 543-561). A sua relação com a moral, com a produção artística e com as atividades cognitivas, revelava sua dinâmica, mas não a sua centralidade, a sua originalidade, o seu teor central (Gehalt). Para Tillich o que faz com que a cultura, logo também a arte, seja algo irmanado à religião, reside na dimensão formativa, original, do espírito humano (CALVANI, 1998, p.76-79). O que é comum a ambas é a preocupação "séria" em vislumbrar as questões últimas da vida, as mais significativas para um concernimento significativo (ultimate concern).

Ao pensar arquitetonicamente a religião, Paul Tillich tem consciência de que o interpelado resiste reduzir-se às formas, às possibilidades e aos limites que a razão investigativa se regra metodologicamente ao lançar-se às perguntas sobre as coisas e os acontecimentos do mundo dos homens e da natureza (TILLICH, 1967, p. 13-31). A princípio, esta distinção inconciliável de saberes mostra-se resistente por conseqüência das atribuições investigativas que a filosofia dispensa na sua rotina reflexiva. Não é por menos, considerada como saber antecâmara das ciências e até mesmo da razão, a filosofia procura estabelecer ou reconstruir a normatividade da especulação objetiva, ética e estética a partir de referenciais internos (logocêntricos - DILTHEY, 1949, p. 81-93). Mesmo que mais tarde este saber torna-se consciente das dimensões falibilistas do pensar, esta normatividade almeja formalizações que inevitavelmente recebem o status de universais, pois a formalização racional é necessária para que a pluralidade dos fenômenos seja coordenada por um sistema de identidades.

Todavia, Tillich é consciente de que o religioso não persegue e nem sobrevive sob as requisições universalistas da razão ocidental. Para ele (1967, p. 13-31), as imagens da(s) religião(ões) buscam cotejar seus participantes ao singular-absoluto arrolado naquilo manifestamente incondicionado. Por isso, uma "revela- 
ção" ou um ato de "redenção" opõe-se a um conceito especulativo e específico de religião. Não por menos, os atos religiosos "originários" 14 rompem com a ordem estabelecida, o cotidiano, no qual se constrói a rotina da ação e do pensamento humano figurados num contexto cultural.

Revelação se refere a uma ação divina, religião a uma ação humana. Revelação é um acontecimento (happening) absoluto, singular, exclusivo e auto-suficiente; religião tema a ver com fatos meramente relativos, sempre recorrentes e nunca exclusivos. Revelação significa a entrada de uma nova realidade na vida e no espírito; religião nos remete à existência da vida e a uma função necessária do espírito. Religião tema a ver com a cultura. . Por esta razão, a religião sente que tem violado sua essência mais profunda quando se denomina religião (TILLICH, 1973, p. 09-10).

Se de um lado a Filosofia da Religião sabe-se distinta da teologia enquanto ciência da revelação, do outro não pode admitir uma imposição de silêncio à razão especulativa - pois tal impotência reflexiva se estenderia também às outras áreas do saber além da própria Filosofia da Religião (TILLICH, 1973, p. 9-10). Para isso, a Filosofia da Religião deve primeiramente reconhecer-se no espaço desta antítese recorrente da existência de uma fronteira entre ciência e fé, onde habitam interesses distintivos, mas nem sempre antagônicos: fé e especulação, e lugar onde trabalham duas ciências nem sempre antagônicas: a filosofia e a teologia (doutrina pensante da revelação - PIEPER, 2015, p.1334-1368). Ao olhar retrospectivamente a história do pensamento ocidental, Tillich (1973) percebe que estas duas grandiosas criações da cultura mantiveram laços de complementaridade (na alta idade média ou no romantismo alemão) ou mesmo de distinção auto-afirmativa

14 É importante notarmos que, para salvaguardar a religião das formas tradicionais de especulação erguidas pela filosofia e pelas ciências sociais, Tillich distingue religiões em mais ou menos pura, original e forte. Talvez, seguindo esta linha de raciocínio, o filósofo e teólogo alemão ainda pense o religioso sob etapas reconstrutivas que postulam uma origem extra-ordinária, como aquela proposta por Rudolf Otto na sua obra Das Heilige (1917), e depois desenvolvida em pesquisas sociais mais amplas como as de Mircea Eliade. Por isso, afirma James Luther Adams que "what is needed is a method of phenomenological intuition and a dynamically developed critical metod. This means that Tillich believes the demand is for the metalogical method" (ADAMS, 1965, p.191). 
(no cartesianismo, no empirismo inglês, criticismo kantiano, no puritanismo anglo-germânico e nos movimentos fundamentalistas do protestantismo norte-americano).

Para o teólogo e filósofo alemão, a luta por uma sobrevivência exclusiva entre estas duas ciências abala tanto as pretensões necessárias de um saber crítico e investigativo como a de um saber necessário do incondicionado da revelação. Por isso, afirma ele, "no entanto, não se pode permitir que subsista a oposição, porque se conduz à ruptura da unidade da consciencia e à disolução tanto da religião quanto da cultura" (TILLICH, 1973, p. 11). Então, cabe a Filosofia da Religião uma solução sintética buscada entre elas, buscando um ponto de convergência para que assim, abram-se possibilidades de uma Filosofia da Religião aliada aos ideais investigativos das ciências humanas, mas sensíveis (sob um olhar hermenêutico) às alteridades simbólicas ancoradas nas formas absolutas e singulares das revelações (JOSAPHAT, 2013, p.71-90.). A "reserva compreensiva" no qual podemos vislumbrar a intimidade entre a literatura e a religião é o binômio central e originário da cultura humana: por um lado, o "dionisíaco" de Nietzsche ou o "fragmentário nada" de Heidegger (experiência de toda a origem artística ou semântica da vida), por outro a luta pulsante comum a todos os homens por refazer, recriar, a ordem significativa do mundo, enquanto preocupação suprema e central à teologia e à religião e que, por isso, tem a sua práxis e o seu teor difundido naquilo que é cultura. ${ }^{15}$

\section{Aspectos Conclusivos}

Tillich (1973, p. 11-18) entende ser importante esclarecer a relação entre a Filosofia da Religião e a Metafísica, embora seja importante evitar qualquer mal-entendido quanto ao sentido empregado ao termo: "metafísica". Sobre metafísica não se deve entender algo como uma ciência sobre os fundamentos últimos

15 Esta dimensão própria e ambígua à humanidade foi muito bem trabalhada na obra: BOFF, 1998. 
do mundo ôntico, mas uma atividade intelectual independente - algo singular a filosofia geral do espírito (Geistesphilosophie überhaupt). Para esclarecer mais ainda a idéia de metafísica, Tillich (1973, p. 11-18) afirma que este saber não pode ser imaginado vinculado ao lado ou acima das ciências, mas de forma independente.

Somente aceitando a independência da metafísica, é possível entender os lugares das ciências e da própria metafísica. Este saber aprimora-se por uma atitude religiosa, a saber, ultimate concern (preocupação última). É por isso que ele aponta ao incondicionado (Richtung auf das Unbedingte) no espaço teórico das "ciências do espírito". Enquanto saber, ele se alia ao estético e ao científico no dirigir-se ao totalmente outro de uma forma simbólica, metafórica e aberta. É através da metafísica que as ciências do espírito resguardam a pergunta inevitável sobre aquilo ainda não se manifestou, pergunta tão podada pelas ciências objetivistas e lógico-formais. Enquanto esta última guia-se pelo horizonte da delimitação e da objetivação, as ciências do espírito brotam investigações atraídas pela dimensão singular e auto-criativa (autopoiesis) do mundo simbólico - ainda mais quando se trata de assuntos religiosos. Quanto ao mais, cabe a nós leitores irmos além destas questões, pois o que nos atraiu até agora foram questões meramente preliminares à ideia de uma Filosofia da Religião.

\section{Bibliografia}

ADAMS, J. L. The philosophy of religion in Paul Tillich's philosophy os culture, science, and religion. New York: Harper e Row, 1965.

ARAÚJO, L. B. L. Weber e Habermas: Religião e Razão Moderna. Síntese Nova Fase. Belo Horizonte, v. 21, nº 64, p. 15-41, 1994.

ASSMANN, J. Religión y memoria cultural. Buenos Aires: Lilmod, Libros de La Araucaria, 2008.

BINGEMER, M. C. L. A experiência do Deus cristão e sua identidade trinitária. In: BINGEMER, M. C.; ANDRADE, P. F. O mistério e a história: ensaios de teologia em homenagem ao Pe. Félix Pastor por ocasião dos seus 70 anos. São Paulo: Loyola, 2003, p. 87-117. 
BOFF, L. O despertar da águia. O diabólico e o simbólico na construção da realidade. Petrópolis: Vozes, 1998.

BOSI, A. B. O romantismo. In: História concisa da literatura brasileira. São Paulo: Cultrix, 2006, p. 91-121.

BRISSON, L. A religião como fundamento da reflexão filosófica e como meio de ação política nas leis de Platão. Kriterion, n.107, 2003, p. 24-38.

BRÜSEKE. F. J. Romantismo, Mística e Escatologia Política. Nova no. 62. São Paulo, 2004.

CALVANI, C. E. B. Teologia e MPB. São Paulo: Edições Loyolas, 1998.

CHAUI, M. A filosofia como vocação a liberdade. Estudos Avançados, n.17, v.49, p.7-15, 2003.

DANZ, C. Tillich's Philosophy. In: Manning, R. R. A. A Cambridge Companion to Paul Tillich. Cambridge: Cambridge University Press, 2001, p.173-188.

DILTHEY, W. Der Aufbau der Geschichtlichen Welt in den Geisteswissenschaften. Vol. VII. Groethuysen, Bernhard, 1968.

DILTHEY, W. El Mundo Histórico. México: Fondo de Cultura Econômica, 1944.

DILTHEY, W. Introduccion a las Ciências Del Espiritu. México: Fondo de Cultura Econômica, 1949.

FREUD, S. Totem e Tabu. Rio de Janeiro: Loyola, 1997.

FREUD, S. O Futuro de uma Ilusão. Rio de Janeiro: Loyola, 1997.

HEIDEGGER, M. Estudios sobre mística medieval. Mexico: Fondo de cultura econômica, 1997.

HEIDEGGER, M. O que é Metafísica?. In: Conferências e escritos filosóficos. São Paulo: Abril Cultural, 1983, p. 46-64.

GROSS, E. O conceito de fé em Paull Tillich, Revista Eletronica Correlatio, v.12, n.23, p. 7-28, 2013.

GROSS, E. Elementos do pensamento de Schelling na obra de Paul Tillich. Numen, Juiz de Fora, v.7, n.2, p.79-99, 2004.

HEGEL, G. W. F. Filosofia da história. Brasilia: EdUNB, 2008.

HIGUET, E. Os métodos da filosofia da religião de Paul Tillich. Revista Eletrônica Correlatio, n. 20, p. 27-41, 2011.

HIGUET, E. A Teologia em programas de Ciências da Religião. Revista Eletrônica Correlatio, n. 10, 2006.

JOSAPHAT, C. Fé e razão. Para alem das crises antinomias, emerge a visão compreensiva das diferenças. Ide, n.36, v. 56, p. 71-90, 2013. 
LADRIÈRE, J. L'Articulation du sens, II. Les langages de la foi. Paris: Cerf, 1984.

MARCUSE, H. Fantasia e utopia. In: Eros e Civilização. Rio de Janeiro: Zahar, 1968, p. 132-145.

MORAES JUNIOR, M. R. de. Hermenêutica, critica e formatação: a virada na compreensão da religião na teoria critica de Max Horkheimer. São Bernardo do Campo. 2010. 205f. Tese (Doutorado em Ciências da Religião) - Universidade Metodista de São Paulo, São Bernardo do Campo: UMESP, 2010.

NIETZSCHE, F. O nascimento da tragédia. São Paulo: Companhia das Letras, 1993.

OTTO, R. O Sagrado. São Bernardo do Campo: Impressa Metodista, 1985.

PALMER, M. Sigmund Freud: psicanálise e religião. São Paulo: Edições Loyola, 2001.

PIERUCCI, A. O desencantamento do mundo. Todos os passos do conceito em Max Weber. São Paulo: Editora 34, 2003.

PIEPER, F. A filosofia da religião e seu objeto em Paul Tillich e Jean-Luc Marion. Horizonte, 2015.

PY, F. Lauro Bretones: um protestante heterodoxo no Brasil de 1948 à 1956, Rio de Janeiro. 2016. 296f. Tese (Doutorado em Teologia) - Pontifícia Universidade Católica do Rio de Janeiro, Rio de Janeiro: PUC-RIO, 2016.

RIBEIRO, C. O. Teologia no Plural. Revista Eletrônica Correlatio, $\mathrm{n}^{\circ} 03$, 2003.

SIEBERT, R. Religião e psicanálise: situação européia. In: CORMIE, L. e SIEBERT, R. A psicologia desafia a fé. Petrópolis: Vozes, p. 27-36, 1982.

STONE, J. A. Tillich and Schelling's Later Philosophy. In: John J. Care (Ed.), Kairós and Iogos. Cambridge: The North American Paul Tillich Society, 1978, p.11-44.

TILLICH, P. El futuro de las Religiones. Buenos Aires: Aurora, 1976.

TILLICH, P. Dimensão religiosa na vida espiritual humana. In: Teologia da Cultura. São Paulo: Fonte Editorial, 2009, p. 37-55.

TILLICH, Paul. Filosofia de la Religión. Buenos Aires: Megalópolis, 1973.

TILLICH, Paul. Religionsphilosophie. In: Frühe Hauptwerke. Gesammelte Werke, Bd. 1, Stuttgart: EvangelischesVerlagswerk, 1959.

TILLICH, P. Über die Idee einer Theologie der Kultur. In: Die religiöse Substanz de Kutur. Schriften zur Theologie der Kultur. Gesammelte Werke (Bd. IX). Stuttgart: 1967, p. 13-31.

TILLICH, P. Dinâmica da fé. São Leopoldo: Sinodal, 1985. 
TILliCH, P. A Era Protestante. São Bernardo do Campo: Metodista, 1992. TILLICH, P. Perspectivas da teologia protestante nos séculos XIX e XX. São Paulo: Aste, 1986.

WEBER, M. Economia y sociedad. Mexico: Fondo de cultura económica, 1999.

WEBER, M. A ética protestante e o espírito do capitalismo. São Paulo: Livraria Pioneira Editora, 1996. 